\title{
PKM PRODUSEN LULUR RUMAHAN: OPTIMALISASI PRODUK “LULUR REMPAH TRADISIONAL BANJAR" MELALUI PENERAPAN TEKNOLOGI FARMASI BAHAN ALAM
}

\author{
Satrio Wibowo Rahmatullah ${ }^{1)}$, Depy Oktapian Akbar ${ }^{2)}$, dan Lisa Andina ${ }^{3)}$, \\ ${ }^{122) 3}$ Sekolah Tinggi Ilmu Kesehatan Borneo Lestari Banjarbaru, Kalimantan Selatan \\ Email : ${ }^{1)}$ ryowibowo46@gmail.com \\ 2) oktadepy@gmail.com \\ 3)lisa_imeru@yahoo.com
}

ABSTRAK : Minat masyarakat terhadap produk kecantikan semakin meningkat baik di kalangan remaja maupun dewasa. Oleh karena itu ketertarikan masyarakat akan lulur rempah tradisional Banjar sebagai salah satu produk kecantikan khas Banjar juga harus ditingkatkan. Produk lulur rempah tradisional Banjar merupakan salah satu produk budaya yang dapat mejadi unggulan dari Kalimantan Selatan, namun pemasarannya masih terbatas karena kurangnya media promosi dan kemasan yang digunakan sangat sederhana (kurang menarik). Produsen lulur rumahan di Martapura merupakan penjual lulur rumahan yang menjadi sasaran kegiatan PKM dari tim pengabdi kepada masyarakat. Kegiatan Pengabdian Masyarakat ini terbagi dalam beberapa tahapan yaitu, Sosialisasi Cara Pembuatan Kosmetika yang Baik (CPKB) pada Pengusaha Industri Lulur Tradisional (Lulur Sari Pengantin), Pelatihan Pembuatan Pedoman Operasional Baku (POB) CPKB pada Industri Lulur Sari Pengantin yang disertai dengan serah terima Mesin Pengemas beserta Kemasan dan Stiker Label Lulur Sari Pengantin. Kegiatan pertama dilaksanakan pada hari selasa 8 mei 2018, Narasumber yang mengisi materi pada acara ini adalah ibu Yuyun Purwaningsih, S.Farm., Apt, yang memberikan materi CPKB terkait higiene, sanitasi, dan dokumentasi. Kegiatan selanjutnya dilaksanakan pada hari senin 30 juli 2018, dengan tema "pelatihan pembuatan pedoman operasional baku (POB) CPKB pada industri lulur sari pengantin” oleh ibu Leny Sanjaya, S.Farm., Apt, dan disertai dengan serah terima mesin pengemas beserta kemasan dan stiker label lulur sari pengantin. Kegiatan ini dihadiri oleh seluruh karyawan beserta pemilik industri lulur sari pengantin, dosen dan mahasiswa stikes borneo lestari. Semua kegiatan ini dilaksanakan di pabrik lulur sari pengantin Jl. Hasyim Muchtar RT.14 Kel. Tanjung rema darat Kec. Martapura.

Kata Kunci: Lulur rempah, Lulur sari pengantin

\section{PENDAHULUAN}

Usaha lulur rempah tradisional adalah usaha yang dilakukan oleh kelompok penjual lulur rempah tradisional melalui peracikan, pencampuran, pengolahan, pengemasan dan pengedaran lulur dalam bentuk serbuk dan dijual melalui warung, toko atau salon dengan fasilitas luluran. Produsen lulur rumahan di Martapura masih merupakan penjual lulur rumahan yang menjadi mitra kegiatan PKM dari tim pengabdi. Bahan baku lulur (simplisia) merupakan produk lokal dari beberapa daerah di Kalimantan Selatan, diantaranya kencur, temulawak, kunyit berasal dari pasar Martapura. Pemasaran lulur rempah tradisional hanya di sekitar kota Martapura, Banjarbaru dan Banjarmasin melalui warung atau toko di pasar Martapura, Banjarbaru dan Banjarmasin. 
Jurnal Mediteg

Volume 3, Nomor 1, Desember 2018

Animo masyarakat terhadap produk kecantikan terus mengalami peningkatan, oleh karena itu animo masyarakat terhadap lulur rempah tradisional Banjar sebagai salah satu produk kecantikan yang kental akan budaya Banjar juga harus ditingkatkan. Produksi lulur rempah tradisional Banjar dapat menjadi salah satu produk budaya unggulan dari Kalimantan Selatan, namun tingkat penjualan lulur rempah tradisional mitra masih belum optimal, hal ini juga disebabkan karena keterbatasan media promosi dan keraguan jaminan kualitas produk yang dihasilkan masih diragukan oleh konsumen. Penjual lulur rumahan setiap bulannya melakukan produksi dengan bantuan tenaga dari warga sekitar, produksi lulur rumahan tidak dilakukan setiap hari tetapi hanya dilakukan pada hari tertentu setiap bulannya. Sebagian proses produksi dilakukan secara manual seperti pencampuran, pengolahan sampai dengan pengemasan

Kelompok mitra menyadari bahwa masalah jaminan kualitas dan keamanan produk lulur yang dihasilkan memang belum dapat dipertanggungjawabkan karena keterbatasan ilmu pengetahuan mengenai pembuatan lulur, yang mana selama ini kelompok mitra membuat produk lulur didasarkan pada pengetahuan empiris dan turun temurun tanpa ada panduan cara pembuatan lulur yang benar dan baik. Berdasarkan diskusi antara tim pengabdian
p-ISSN : 2548-7655

e-ISSN : 2614-0489

dengan mitra (Kelompok Penjual Lulur Rempah Tradisional) diketahui permasalahan yang mereka hadapi adalah: bagaimana mengurangi biaya produksi terutama pada pemilihan bahan baku (simplisia) yang berkualitas, pengolahan bahan baku (simplisia) menjadi lulur dengan benar serta meningkatkan daya jual lulur melalui perbaikan produk kemasan disertai dengan jaminan kualitas dan keamanan produk lulur tersebut.

Saat ini jaminan kualitas dan keamanan produk lulur yang dijual mitra akan memberikan ketenangan pada konsumen serta meningkatkan daya beli konsumen karena merasa terjamin bahwa lulur yang mereka gunakan betul-betul berkhasiat serta tidak membahayakan (Wirya, 2006). Tujuan dari kegiatan ini yaitu: 1) Produsen lulur dapat mengaplikasikan produksi lulur berbasis $\mathrm{CPKB}$ dan distributor bahan baku pemasok lulur dapat mengaplikasikan penyediaan bahan baku berbasis CPKB, 2) Produsen memiliki manual praktis produksi lulur, 3) produsen mampu meaplikasikan pengemasan produk yang menarik, dan 4) Produsen mampu meaplikasikan teknik pemasaran secara modern. 
Jurnal Mediteg

Volume 3, Nomor 1, Desember 2018

\section{METODE \\ PELAKSANAAN KEGIATAN}

Kegiatan ini dilaksanakan di pabrik Lulur Sari Pengantin Jl. Hasyim Muchtar RT.14 Kel. Tanjung rema darat Kec. Martapura. Kegiatan ini dilaksanakan secara bertahap, tahap yang pertama dilaksanakan pada tanggal 8 Mei 2018 dengan tema Sosialisasi Cara Pembuatan Kosmetika yang Baik (CPKB) pada Pengusaha Industri Lulur Tradisional. Tahap elanjutnya dilaksanakan pada tanggal 30 Juli 2018 dengan tema pelatihan pembuatan pedoman operasional baku (POB) CPKB pada industri lulur sari pengantin.

Kegiatan ini dihadiri oleh 40 peserta yang terdiri dari pimpinan beserta karyawan Industri Lulur Sari Pengantin, Tim dosen dan mahasiswa STIKES Borneo Lestari. Metode pelaksanaan pada kegiatan ini dilakukan dengan mensosialisasikan materi tentang $\mathrm{CPKB}$, selain mensosialisasikan materi tentang $\mathrm{CPKB}$, dilaksanakan juga kegiatan pelatihan pembuatan pedoman operasional baku (POB) CPKB pada industri lulur sari pengantin"

Sosialisasi dan pelatihan ini dilaksanakan dengan media berupa Laptop, LCD, Materi yang dibagikan kepada masing-masing peserta, contoh POB CPKB dari BBPOM. Setelah penyampaian materi selesai dilaksanakan juga sesi tanya jawab untuk mengetahui pemahaman peserta terhadap materi yang

$$
\text { p-ISSN : 2548-7655 }
$$

e-ISSN : 2614-0489

sudah disampaikan. Peserta juga langsung dilibatkan dalam pembuatan beberapa POB $\mathrm{CPKB}$, sehingga di akhir acara sudah terdapat contoh beberapa POB CPKB pada Industri Lulur Sari Pengantin.

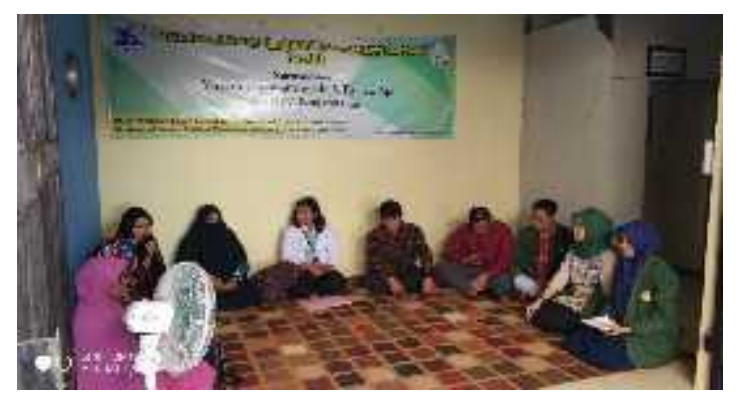

\section{HASIL DAN PEMBAHASAN}

1. Sosialisasi Cara Pembuatan Kosmetika yang Baik (CPKB) pada Pengusaha Industri Lulur Tradisional (Lulur Sari Pengantin)

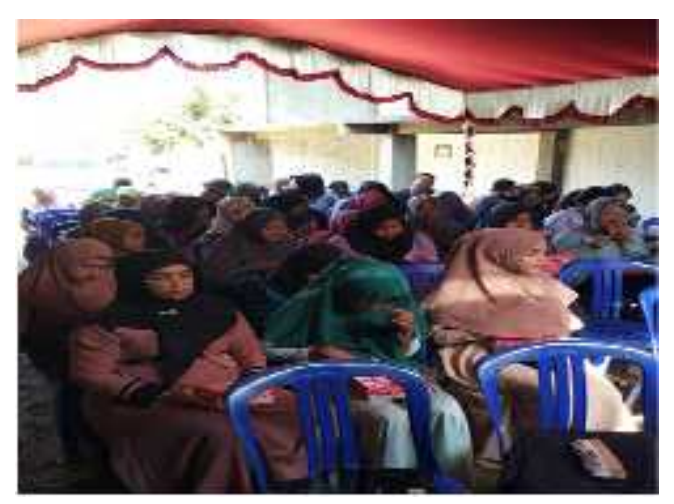


Jurnal Mediteg

Volume 3, Nomor 1, Desember 2018
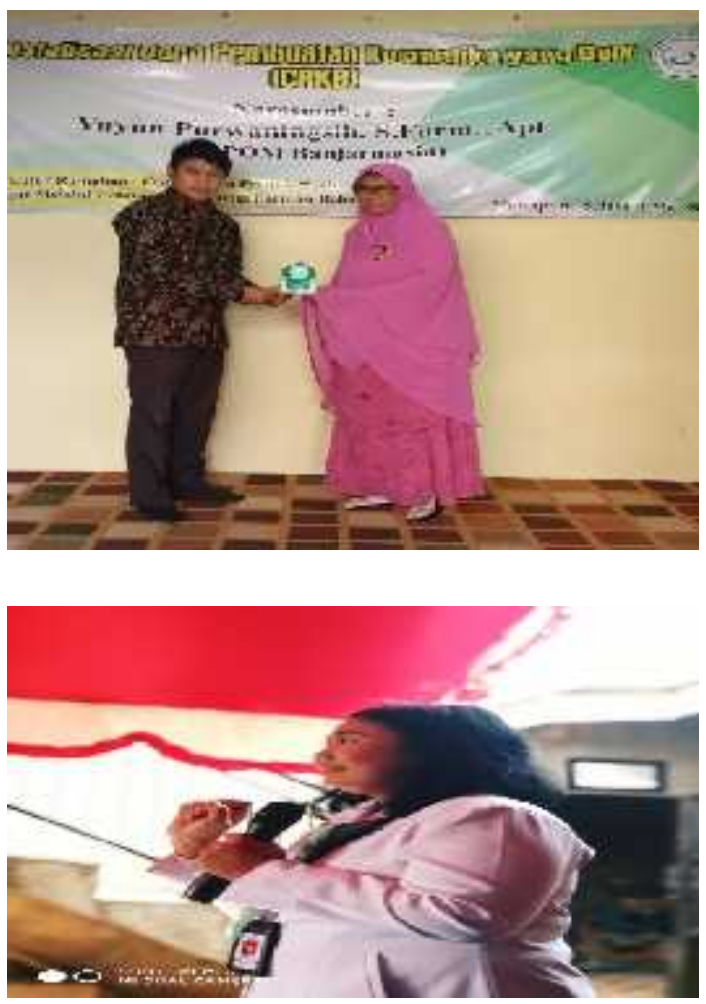

Gambar 1. Kegiatan Sosialisasi Cara Pembuatan Kosmetika yang Baik (CPKB) pada Pengusaha Industri Lulur Tradisional (Lulur Sari Pengantin)

Kegiatan ini dimulai dengan melakukan survey ke Industri Lulur Sari Pengantin Tradisional Khas Banjar, melakukan diskusi tentang rangkaian acara pengabdian kepada masyarakat yang dilaksanakan pada tanggal 8 Mei 2018 di Pabrik Lulur Sari Pengantin Jl. Hasyim Muchtar RT.14 Kel. Tanjung Rema Darat Kec. Martapura.

CPKB merupakan salah satu faktor penting untuk dapat menghasilkan produk kosmetik yang memenuhi standar mutu dan keamanan (BPOM, 2003). Mengingat pentingnya penerapan $\mathrm{CPKB}$ maka dilaksanakan Kegiatan Sosialisasi CPKB
p-ISSN : 2548-7655

e-ISSN : 2614-0489

Pada Pengusaha Lulur tradisional Lulur Sari Pengantin. Kegiatan ini dihadiri oleh seluruh karyawan beserta pemilik industri Lulur Sari Pengantin, Dosen dan Mahasiswa STIKES Borneo Lestari. Materi disampaikan oleh narasumber yang berasal dari Balai Besar POM Banjarmasin, Ibu Yuyun Purwaningsih, S.Farm., Apt, dalam materi yang disampaikan, beliau mengatakan bahwa untuk memproduksi suatu kosmetika golongan B yang akan dipasarkan tidak cukup hanya dengan menggunakan pengalaman empiris secara turun-temurun, tetapi juga harus memenuhi aspek CPKB yaitu Higiene Sanitasi dan Dokumentasi (BPOM, 2016). Hal ini dilakukan untuk menjamin mutu dan keamanan kosmetika yang akan digunakan. Setelah materi seselai disampaikan, dilaksanakan juga sesi tanya jawab dengan tujuan untuk mengetahui tingkat pemahaman peserta terhadap materi yang telah disampaikan, diakhir acara dilakukan penyerahan kenang-kenangan untuk Narasumber dan Industri Lulur Sari Pengantin.

2. Pelatihan Pembuatan Pedoman Operasional Baku (POB) CPKB pada Industri Lulur Sari Pengantin

Berdasarkan analisis situasi dan permasalahan mitra yang telah dikemukakan 
Jurnal Mediteg

Volume 3, Nomor 1, Desember 2018

terkait kelengkapan Pedoman Operasional Baku (POB) pada Industri Lulur Sari Pengantin, maka dilaksanakan "Pelatihan Pembuatan Pedoman Operasional Baku (POB) CPKB pada Industri Lulur Sari Pengantin". Narasumber yang mengisi materi pada acara ini adalah Ibu Leny Sanjaya, S.Farm., Apt, yang memberikan materi tentang POB CPKB. Acara ini dilaksanakan pada hari Senin 30 Juli 2018 di Pabrik Lulur Sari Pengantin Jl. Hasyim Muchtar RT.14 Kel. Tanjung Rema Darat Kec. Martapura dan dihadiri oleh seluruh karyawan beserta pemilik industri Lulur Sari Pengantin, Dosen dan Mahasiswa STIKES Borneo Lestari.
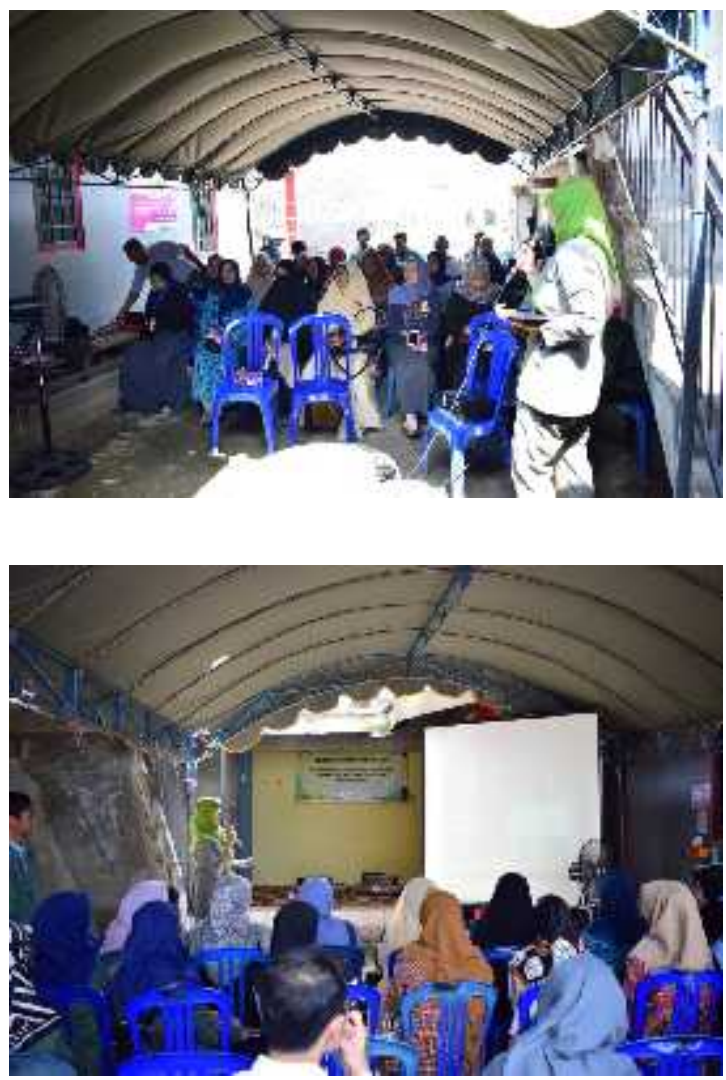

p-ISSN : 2548-7655

e-ISSN : 2614-0489

Kegiatan ini dimulai dengan menjelaskan arti penting dari Pedoman Operasional baku dalam sebuah industri, khususnya industri Lulur Sari Pengantin sesuai dengan Peraturan Kepala BPOM RI tentang Pedoman Penerapan Higiene Sanitasi dan Dokumentasi pada Kosmetika Golongan B. Setelah selesai sesi penyampaian materi, semua peserta dilatih untuk dapat membuat beberapa POB yang terkait CPKB di Industri Lulur Sari Pengantin, dan hasilnya seluruh peserta berhasil membuat $\mathrm{POB}$ terkait $\mathrm{CPKB}$ dengan Baik. POB yang dibuat sangat bermanfaat antara lain sebagai standarisasi karyawan dalam melaksanakan tugas, mengurangi tingkat kesalahan dan kelalaian yang mungkin dilakukan oleh seorang karyawan, serta sebagai pedoman dalam melaksanakan pekerjaan rutin (BPOM, 2003).

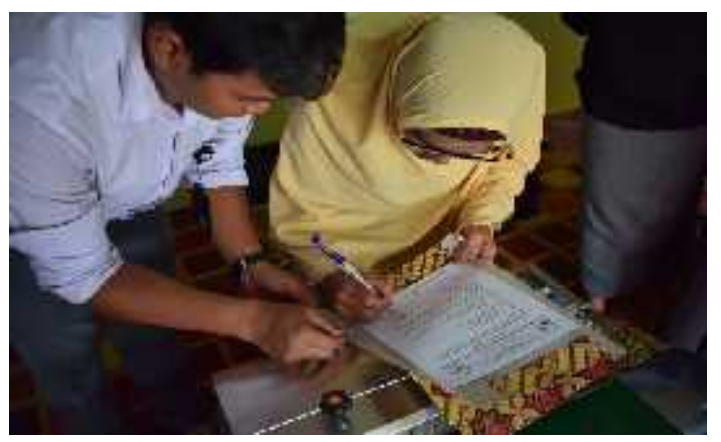


Jurnal Mediteg

Volume 3, Nomor 1, Desember 2018
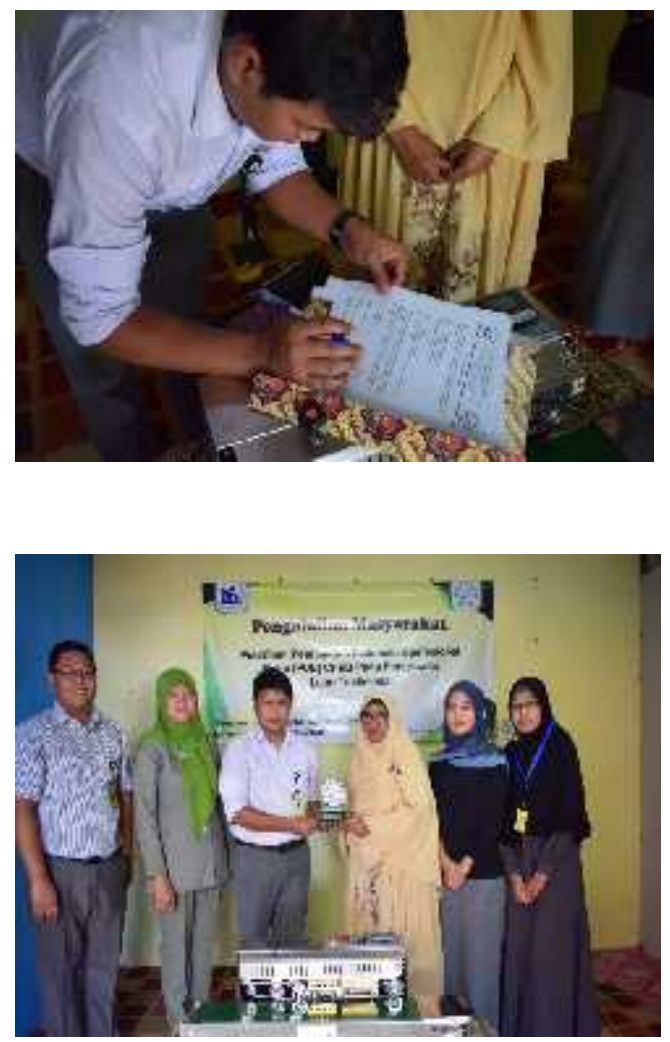

Selanjutnya dilakukan serah terima 2 unit mesin Continuous Sealer FR Vertical Horizontal dan kemasan aluminium foil beserta label oleh ketua Tim PkM kepada pimpinan industri lulur sari pengantin. Alat dan kemasan yang di serahkan akan digunakan untuk meningkatkan mutu, kualitas dan nilai jual dari Lulur sari pengantin. Diakhir acara dilakukan penyerahan kenang-kenangan untuk Narasumber dan Industri Lulur Sari Pengantin.

\section{KESIMPULAN}

Kesimpulan yang dapat diperoleh dari kegiatan ini adalah untuk memproduksi suatu kosmetika Golongan B yang akan
p-ISSN : 2548-7655

e-ISSN : 2614-0489

dipasarkan tidak cukup hanya dengan menggunakan pengalaman empiris secara turun-temurun, tetapi juga harus memenuhi aspek CPKB yaitu Higiene Sanitasi dan Dokumentasi. POB yang dibuat sangat bermanfaat antara lain sebagai standarisasi karyawan dalam melaksanakan tugas, mengurangi tingkat kesalahan dan kelalaian yang mungkin dilakukan oleh seorang karyawan, serta sebagai pedoman dalam melaksanakan pekerjaan rutin.

\section{DAFTAR PUSTAKA}

BPOM, 2003, Nomor :HK.00.05.4.3870 tentang Pedoman Cara Pembuatan Kosmetik yang Baik

BPOM, 2016, Pedoman Penerapan Higiene Sanitasi dan Dokumentasi pada Industri Kosmetika Golongan B, Peraturan Kepala Badan Pengawas Obat dan Makanan nomor 11 tahun 2016.

Wirya I. 2006. Kemasan yang Menjual, PT. Gramedia Pustaka Utama, Jakarta 